Przeglad SejMowy

nr 6(161)/2020, s. 223-231; https://doi.org/10.31268/PS.2020.90

\title{
Republika Singapuru: wyrok Sądu Apelacyjnego z 30 czerwca 2020 r. w sprawie Daniel De Costa Augustin vs. Attorney-General (dotyczący realizacji prawa do głosowania w wyborach parlamentarnych zarządzonych w czasie pandemii koronawirusa), sygn. [2020] SGCA 60
}

Parlament Singapuru trzynastej kadencji został rozwiązany 23 czerwca 2020 r. Pomimo trwającej pandemii koronawirusa SARS-CoV-2 oznaczało to, zgodnie z art. 66 Konstytucji Republiki Singapuru z 1965 r., konieczność przeprowadzenia wyborów parlamentarnych. Ustawodawca ustanowił jednak specjalne reguły procedury wyborczej w związku z trwającą pandemią koronawirusa. Specjalna regulacja ustawowa została przyjęta 4 maja $2020 \mathrm{r}$. Wprowadzono m.in. rozwiązania mające na celu stworzenie osobom odizolowanym z powodu koronawirusa możliwości oddania głosu poprzez organizację wyborów w miejscach masowej izolacji, takich jak hotele czy domy studenckie. Rozwiązania przewidziane w tej regulacji stały się przedmiotem skargi sądowej złożonej przez obywatela Singapuru Daniela De Costa Augustina. Podniesiono, że środki ostrożności, których podjęcie jest konieczne do ochrony zdrowia publicznego w czasie pandemii, skutkują pozbawieniem wyborców prawa do wolnych i uczciwych wyborów. Sąd w wyroku stwierdził, że skarżący nie wykazał, iż przyjęte rozwiązania naruszyły prawo do głosowania, wskazując w szczególności, że kwestie zdrowotne nie są związane z prawem do głosowania i powinny być rozpatrywane odrębnie jako kwestia zdrowia publicznego, co nie było przedmiotem żadnej skargi złożonej do Sądu Apelacyjnego.

SŁowa KLUCzowe: wybory, prawo do głosowania, koronawirus, Republika Singapuru

\section{Republic of Singapore: judgement of the Court of Appeal of 30 June 2020 in the case of Daniel De Costa Augustin vs. Attorney-General (concerning the exercise of the right to vote in parliamentary elections ordered during the coronavirus pandemic), No. [2020] SGCA 60}

The Parliament of Singapore of the 13th parliamentary term was dissolved on 23 June 2020. Despite the ongoing SARS-CoV-2 coronavirus pandemic, this meant, in accordance with Article 66 of the 1965 Constitution of the Republic of Singapore, that the parliamentary elections had to be held. However, the legislator has established special rules for the election procedure in connection with the ongoing coronavirus pandemic. A special statutory regulation was adopted on 4 May 2020. Among other things, solutions have been introduced to give people isolated due to the coronavirus the opportunity to vote by organizing elections in places of mass isolation, such as hotels or student dormitories. The solutions provided for in this regulation have been the subject of a court complaint filed by Daniel De Costa Augustin, a Singapore citizen. In the complaint it was argued that the precautionary measures needed to protect public health at the present time have the effect of depriving voters of the right to free and fair elections. In the judgement, the Court of Appeal found that the applicant had failed to show that the adopted 
solutions violated the right to vote. In particular, it pointed out that health issues are not related to the right to vote and should be dealt with separately as a public health issue, which was not the subject of any action brought before the Court of Appeal.

KEY wORDS: elections, right to vote, coronavirus, Republic of Singapore

Fakty: Wybory parlamentarne w Singapurze odbywaja się, podobnie jak $w$ większości ustrojów demokratycznych, tuż przed upływem kadencji parlamentu, której dtugość $w$ Singapurze wynosi 5 lat. Podobnie jednak jak w niektórych innych państwach, głównie monarchiach, możliwe jest rozwiazanie parlamentu przed uptywem kadencji (taka możliwość występuje przykładowo w Danii, Austrii czy Holandii, a do 2011 r. również $w$ Wielkiej Brytanii). Kompetencje w tym zakresie posiada prezydent Singapuru, działając na wniosek premiera tego państwa. Parlament Singapuru trzynastej kadencji zostat rozwiazany 23 czerwca 2020 r. Pomimo trwającej pandemii koronawirusa SARS-CoV-2 oznaczało to, zgodnie z art. 66 Konstytucji Republiki Singapuru z 1965 r., konieczność przeprowadzenia wyborów parlamentarnych (zwanych $w$ Singapurze wyborami generalnymi, pomimo że nie sa przeprowadzane z innego rodzaju wyborami powszechnymi, w szczególności prezydenckimi) kilka tygodni przed planowanym terminem.

Ustawodawca ustanowit jednak specjalne reguty procedury wyborczej $w$ zwiazku z trwająca pandemia koronawirusa. Specjalna regulacja ustawowa została przyjęta 4 maja 2020 r. Dotyczyła ona obowiązu głosowania. W Singapurze głosowanie jest bowiem obowiąziem obywateli (co charakterystyczne, prawo do głosowania uzyskuje się dopiero $w$ dniu ukończenia 21. roku życia), zaś w przypadku nieoddania głosu $w$ wyborach wyborca jest wykreślany z rejestru wyborców i przed kolejnymi wyborami musi się samodzielnie ponownie zarejestrować, jeśli chce oddać głos. Zgodnie z incydentalna regulacją obywatele, którzy przebywaja na kwarantannie lub w związku pandemia musza pozostać w domu w dniu głosowania, nie zostaja wykreśleni z rejestru wyborców. Ponadto zgodnie z ustawa głosowanie nie stanowi uzasadnienia opuszczenia miejsca odbywania kwarantanny i zagrożone jest kara grzywny. Wprowadzono również rozwiązania mające na celu stworzenie osobom odizolowanym z powodu koronawirusa możliwości oddania głosu poprzez organizację wyborów w miejscach masowej izolacji, takich jak hotele czy domy studenckie. Warunkiem organizacji głosowania $w$ takich miejscach jest jednak przebywanie tam więcej niż jednej osoby w związu z koniecznościa poszanowania zasady tajności głosowania. W przypadku braku możliwości głosowania osoby objęte izolacja transportowane sa do specjalnego lokalu wyborczego, w którym maja możliwość oddać głos. W lokalu wyborczym wyborcy sa zobowiazani do noszenia masek zakrywajacych usta oraz nos, jednak w celu weryfikacji tożsamości przed otrzymaniem karty do głosowania powinni odsłonić twarz przed członkiem komisji wyborczej.

Skarga (nr 614/2020) została złożona przez obywatela Singapuru mieszkajacego na terytorium tego kraju w tym samym dniu, w którym został rozwiąany parlament 
i zostały zarządzone wybory, tj. 23 czerwca 2020 r. Z uwagi na bliskość terminu głosowania w wyborach, które zostaly ustalone na dzień 10 lipca 2020 r., sprawa byta rozpatrywana w trybie pilnym. Poczatkowo ustalony termin rozprawy na dzień 2 lipca $2020 \mathrm{r}$. zostat przesunięty na prośbę skarżacego na dzień poprzedzająy ostateczny termin na zgłoszenie kandydatów w wyborach (30 czerwca 2020 r.). Sprawa została rozpatrzona 29 czerwca 2020 r. przez Sąd Najwyższy, który oddalit skargę. Daniel De Costa Augustin jeszcze w tym samym dniu zlożyt odwotanie (nr 101/2020) do wyższej izby Sadu Najwyższego - Sadu Apelacyjnego. Rozpatrzenie odwołania zostało wyznaczone na dzień 30 czerwca 2020 r. Oba te wyroki z uwagi na pilność sprawy miaty charakter ex tempore. Przedmiotem niniejszego tlumaczenia jest drugi z wymienionych wyroków ${ }^{1}$.

Wybory zostaly ostatecznie przeprowadzone 10 lipca 2020 r., jednak z uwagi na strefy czasowe dzień wcześniej głosowała część wyborców przebywających za granica (w lokalach wyborczych znajdujących się na zachodniej pótkuli). Należy w tym miejscu zauważyć, że obywatel Singapuru przebywajacy $w$ dniu głosowania poza granicami kraju zachowuje prawo do głosowania pod warunkiem posiadania obywatelstwa Singapuru, ukończenia 21. roku życia, ale również przebywania na terytorium Singapuru przez minimum 30 dni w ciagu ostatnich 3 lat. Spetnienie tych warunków stwarza możliwość - po dokonaniu czynności rejestracyjnych — oddania głosu w kraju w obwodzie głosowania właściwym ze względu na miejsce, w którym wyborca posiada nieruchomość mieszkalna, a w razie jej braku - miejsce zamieszkania bliskich krewnych. Istnieje równiez możliwość oddania głosu w jednym z 10 miast świata z największq liczba obywateli Singapuru, w którym organizowane jest takie glosowanie. Tymi miastami sa: Canberra, Londyn, Tokio, Pekin, Waszyngton, Hongkong, Szanghaj, Dubaj, Nowy Jork oraz San Francisco. Dla wielu obywateli Singapuru chęć oddania głosu oznaczała jednak konieczność dokonania wyboru pomiędzy podróża do ojczyzny a podróża do innego państwa, w którym organizowane jest głosowanie. W czasie pandemii koronawirusa znacznym utrudnieniem okazały się ograniczenia w podróżowaniu obowiazujące $w$ okresie wyborów parlamentarnych $w$ Singapurze $w$ wielu państwach świata ( $w$ tym obowiazkowa kwarantanna), co w praktyce pozbawiało wielu obywateli Singapuru faktycznej możliwości oddania głosu w wyborach.

\section{Wprowadzenie}

1. W dniu 23 czerwca 2020 r. prezydent Singapuru rozwiązał parlament oraz zarządził wybory generalne w 2020 roku [dalej: wybory] zgodnie z art. 65 ust. 3 Konstytucji Republiki Singapuru [dalej: konstytucja] oraz art. 24 ust. 1 ustawy o wyborach

${ }^{1}$ Treść wyroku została opublikowana na stronie internetowej <www.supremecourt.gov.sg>, dostęp: 28 VII 2020. 
parlamentarnych [dalej: ustawa - przyp. M.R.]. W tym samym dniu apelujący złożył wniosek (HC/OS614/2020) o sądową kontrolę i 1) stwierdzenie, że prawo do głosowania, jak również wolne i uczciwe wybory stanowią fundamentalne prawa zagwarantowane w konstytucji, oraz 2) wydanie zarządzenia zakazującego przeprowadzenia wyborów. W uzasadnieniu apelujący wyjaśnił, że przeprowadzenie wyborów w zaplanowanym terminie w sytuacji, gdy jesteśmy w trakcie globalnej pandemii choroby wywołanej koronawirusem (COVID-19), spowoduje zagrożenie prawa do głosowania, a także wolnych oraz uczciwych wyborów i dlatego muszą one zostać przełożone. $[\ldots]$

2. COVID-19 jest wysoce zaraźliwą oraz potencjalnie zagrażającą życiu chorobą. Spowodowała ona nagłe i dramatyczne zmiany w wielu aspektach codziennego życia, czego jednym z przejawów jest fakt, że Sąd Apelacyjny zwołał dziś rano wideokonferencję w celu rozpatrzenia przedmiotowej skargi [...]. Jest oczywiste, że bez skutecznej szczepionki ryzyko zakażenia jest tak wysokie, że konieczne jest powzięcie radykalnych i szybkich kroków w celu ograniczenia stanu zagrożenia zdrowia publicznego. Odpowiednie środki powinny obejmować zachowanie obowiązkowego dystansu społecznego, noszenie maseczek ochronnych, 14-dniowy okres kwarantanny, a także ograniczenia w zakresie liczby uczestników publicznych zgromadzeń. Z perspektywy wyborów ustawa $\mathrm{nr} 21 \mathrm{z} 2020 \mathrm{r}$ o wyborach parlamentarnych (specjalne uregulowania związane z COVID-19) przyjęta w dniu 4 maja 2020 r. określa zmiany w procedurze wyborów dostosowujące do obecnej sytuacji, w tym procedurę kontroli wyborców pod względem możliwego zakażenia COVID-19 w celu minimalizacji zagrożenia zdrowia publicznego.

3. Apelujący nie kwestionuje konstytucyjności tej ustawy, ale podnosi, że środki ostrożności, których podjęcie jest konieczne do ochrony zdrowia publicznego w obecnym czasie, skutkują pozbawieniem wyborców prawa do wolnych i uczciwych wyborów, ponieważ m.in. dyskryminują partie opozycyjne. Globalne restrykcje wprowadzone w celu zwalczenia COVID-19 oznaczają, że wyborcy przebywający poza granicami kraju nie mogą skorzystać ze wszystkich sposobów oddania głosu, co w rezultacie ogranicza ich prawo do głosowania. Pojawiają się również wątpliwości w zakresie bezpieczeństwa członków komisji wyborczych, którzy będę narażeni na niepotrzebne ryzyko mogące skutkować zakażeniem COVID-19. Z tych, jak również wielu innych powodów apelujący podnosi, że najwyższy urzędnik wyborczy [Returning Officer — przyp. M.R.] powołany przez Ministra na podstawie art. 3 ust. 1 ustawy powinien zarządzić wstrzymanie procedury wyborczej.

4. Jak wskazano powyżej, skarżący wniósł sprawę w tym samym dniu, w którym został rozwiązany parlament oraz zarządzone zostały wybory. Na wniosek skarżącego, aby sprawa została rozpatrzona przed terminem zgłaszania kandydatów, który przypada dzisiaj, wniosek został zaplanowany do rozpatrzenia przez sędziów Sądu Najwyższego [dalej: sędziowie] w dniu wczorajszym. Apelujący wyraził swoją wolę w zakresie złożenia skargi i sąd zebrał się w celu jej rozpatrzeniu w trybie przyśpieszonym dziś rano. 


\section{Wyrok w sprawie}

5. Przed wydaniem wyroku w sprawie oraz przedstawieniem jego uzasadnienia zasadne jest wskazanie kilku argumentów, którymi posłużył się apelujący:

a) Apelujący nie kwestionuje decyzji o rozwiązaniu parlamentu. Przedstawiciel apelującego, Pan Ravi [dalej: pełnomocnik apelującego — przyp. M.R.], przekazał dziś rano informację, że w żadnym razie nie kwestionuje decyzji o rozwiązaniu parlamentu. W tym miejscu należy przytoczyć art. 65 ust. 3 konstytucji, zgodnie z którym w sytuacji, gdy premier posiadający poparcie większości członków parlamentu rekomenduje prezydentowi rozwiązanie parlamentu, prezydent jest zobowiązany tego dokonać [...];

b) Prowadzi to do art. 66 konstytucji, który stanowi, że: „Po każdym rozwiązaniu parlamentu w ciągu 3 miesięcy powinny zostać przeprowadzone wybory generalne, które prezydent powinien [...] zarządzić". Pełnomocnik apelującego nie powołał się wprawdzie na ten przepis, jednak w naszej opinii jest on kluczowy dla rozstrzygnięcia sprawy. W sytuacji, gdy rozwiązanie parlamentu nie jest kwestionowane, przepis konstytucyjny stanowi, iż wybory generalne powinny zostać przeprowadzone w okresie 3 miesięcy, i nie jest wcale oczywiste, że Sąd może wstrzymać procedurę wyborczą. Należy podkreślić, że apelujący nie oparł się na konkretnym zarzucie, lecz dąży do wstrzymania procedury wyborczej.

6. Przechodząc do rozpatrzenia argumentów, które przedstawił pełnomocnik apelującego, pozostawiając na marginesie istotne ograniczenia, które przedstawiliśmy wyżej, wynikające z brzmienia art. 65 ust. 6 oraz art. 66, w pierwszej kolejności należy wskazać, że pełnomocnik podkreśla, iż apelujący opiera się na przekonaniu, zgodnie z którym obywatele Singapuru posiadają fundamentalne prawo do głosowania. W dalszej części wniosku strona apelująca posługuje się bardziej ogólnym zarzutem naruszenia prawa do wolnych i uczciwych wyborów. Rozpatrując ten zarzut, konieczne jest rozważenie następujących kwestii:

a) natury, źródła oraz treści tego prawa,

b) specyficznego sposobu, w którym prawo to zostało zagrożone lub naruszone,

c) podstawy, na której apelujący opiera swoje prawo do ochrony tego prawa.

\section{Prawo do głosowania}

7. Przechodząc do kwestii prawa do głosowania [...], należy zauważyć, że jak wynika z art. $66 \mathrm{w}$ zw. z art. 65 ust. 3 konstytucji, w sytuacji, gdy parlament zostaje rozwiązany, konstytucja nakłada na władze państwowe obowiązek przeprowadzenia wyborów generalnych. Odpowiednio art. 39 ust. 1 stanowi o członkach parlamentu wybieranych w wyborach generalnych. Termin ,wybory generalne” nie jest zdefiniowany, jednak oznacza wybory powszechne, w których obywatele wybierają swoich przedstawicieli w parlamencie. $\mathrm{W}$ dalszej kolejności prowadzi to do wyboru premiera, który zgodnie z art. 25 jest członkiem parlamentu dającym rękojmię uzyskania poparcia 
większości parlamentarnej. Procedura ta stanowi istotę westminsterskiego modelu rządu, który znajduje odzwierciedlenie w strukturze instytucjonalnej ustanowionej w przepisach konstytucyjnych. [...]

8. Prokurator generalny nie zakwestionował powyższych twierdzeń przedstawionych przez stronę apelującą. Jednakże pragniemy uściślić jedno z twierdzeń. Pełnomocnik apelującego opisał prawo do głosowania jako prawo enumeratywne. Nie zgadzamy się z taką klasyfikacją. Pojęcie praw enumeratywnych zostało odrzucone w wyroku w sprawie Yong Vui Kong vs. Public Prosecutor [2015]2SLR 1129 [...], w którym Sąd zauważył, że: „W naszym orzeczeniu, w związku z tym, że prawo nie wynika z konstytucji (czy to wprost, czy to w drodze wykładni), sądy nie mają kompetencji do kreowania takiego prawa z ogółu przepisów tylko dlatego, iż uważają, że jest ono potrzebne czy też, być może wyrażając się w sposób bardziej pryncypialny, że jest częścią prawa naturalnego. [...] Wyprowadzanie praw nieenumeratywnych z konstytucji stawiałoby sędziów w roli superprawodawców, wprowadzając do prawa ich osobiste poglądy w zakresie tego, co jest potrzebne i sprawiedliwie, co byłoby nie tylko niedemokratyczne, ale również przeciwstawne do rządów prawa".

9. Zgodnie z orzecznictwem Sądu prawo do głosowania powinno być rozumiane jako prawo, które wynika z konstytucji wprost lub też pośrednio, poprzez odniesienie się do art. 66 oraz art. 39 ust. 1 konstytucji. Pełnomocnik apelującego, jak się wydaje, zaakceptował ten fakt $\mathrm{w}$ toku rozprawy.

10. Fakt, że prawo to nie jest dyskusyjne, jest istotny w związku z przedmiotem sprawy, którym jest stwierdzenie, iż prawo do głosowania jest prawem deklaratoryjnym i stanowi warunek dalszego procedowania sprawy. Pełnomocnik apelującego stwierdził jednak, że oczekiwał deklaracji, zgodnie z którą prawo do głosowania stanowi część podstawowej struktury konstytucji $\mathrm{i} \mathrm{w}$ tym znaczeniu jest fundamentalnym prawem, które nie może być uchylone przez parlament. Sposób, w jaki argument ten został przedstawiony, jest jednak niewłaściwy. Prawo do głosowania stanowi bez wątpienia konstytucyjne prawo i zgodnie z art. 4 konstytucji powinna istnieć możliwość zakwestionowania każdego prawa, które jest z nim sprzeczne. Jednakże odwołanie się do doktryny podstawowej struktury [basic structure doctrine — przyp. M.R.] oraz sugestie pełnomocnika apelującego, że prawo to zostało zaakceptowane jako część prawodawstwa Singapuru, są błędne. W sprawie Yong Vui Kong stwierdziliśmy, że: „Zakreśliliśmy powyżej ramy doktryny podstawowej struktury konstytucji, aby wykazać, że doktryna ta nie jest dopuszczalna $\mathrm{w}$ niniejszej sprawie: $\mathrm{w}$ sposób oczywisty nie ma bowiem nic w systemie rządów ustanowionym w naszej konstytucji, co wymagałoby stwierdzenia, że zakaz tortur stanowi część jej podstawowej struktury. [...] W sprawie Kesavanada Bharati vs. State of Kerala AIR 1973 S.C. 1461 Sąd stwierdzil, że podstawowa struktura Konstytucji nie może zostać zmieniona nawet $\mathrm{w}$ drodze poprawki konstytucyjnej, przyjętej zgodnie z przepisami [...]".

11. [...] Przedmiot niniejszej sprawy nie dotyczy poprawki konstytucyjnej, w związku z czym nie występuje zagadnienie związane ze wskazaną wyżej doktryną. Pełnomocnik apelującego nie sprzeciwił się temu. 
12. Z powyższego wynika, że nie ma sporu w zakresie istnienia konstytucyjnego prawa do głosowania, w związku z czym wniosek o wydanie wyroku deklaratoryjnego nie może być procedowany. Jak przyznał pełnomocnik apelującego, jego wniosek o wydanie zarządzenia zabezpieczającego był uzależniony od wymienionego wniosku o stwierdzenie istnienia prawa do głosowania, co stanowi podstawę od oddalenia apelacji. $[\ldots]$

\section{Brak kontrowersji w zakresie prawa do wolnych i uczciwych wyborów}

13. Oczywiste jest, że apelujący tak naprawdę nie ma podstaw do złożenia skargi (a tym samym apelacji) dotyczącej prawa do głosowania. Kluczową kwestią dla strony dążącej do ochrony tego prawa jest ustalenie precyzyjnej jego treści oraz wykazanie, że zostało ono naruszone. Jak podnosił pełnomocnik apelującego, samym jądrem tego prawa jest uprawnienie obywateli Singapuru do oddania głosu w wyborach. W sytuacji, gdy wybory zostały zarządzone, nie ma żadnych podstaw do twierdzenia, że prawo to zostało w jakikolwiek sposób zagrożone. Pełnomocnik strony wyjaśnił następnie, że prawo do głosowania obejmuje prawo do uczciwych i wolnych wyborów. Jakkolwiek zgadzamy się, że wybory powinny być wolne i uczciwe, to określenie warunków, jakie muszą spełniać wolne i uczciwe wybory, jest sporne i to na stronie apelującej spoczywa obowiązek wykazania, że trwające wybory nie spełniają wymogów konstytucyjnych w tym zakresie. Pełnomocnik apelującego opiera się na kilku argumentach [...]:

a) powołał się na art. 8 ustawy z dnia 4 maja 2020 r. wyłączający zakaz dotyczący urzędnika wyborczego oraz dyrektora Służb Medycznych, a także osób podległych im służbowo do prowadzenia skierowanych do osób, które wykazują objawy chorób oddechowych lub grypy, jak również były narażone na zakażenie COVID-19, działań informacyjnych mających na celu rezygnację przez te osoby z oddania głosu w wyborach. Podniósł, że takie działania mogą doprowadzić do rezygnacji z głosowania przez istotną część elektoratu. Pytany o to, jakich konkretnie grup to dotyczy i w jaki sposób, pełnomocnik apelującego nie był jednak w stanie tego satysfakcjonująco wyjaśnić. Jak wskazaliśmy, przepisy te wyłączają jedynie dwóch urzędników państwowych (oraz osoby podległe im służbowo) spod zarzutów o naruszenie zakazu zachęcania wyborców do rezygnacji z głosowania zgodnie z art. 81 ust. 1 ustawy. Ponadto komunikaty tych osób mają charakter doradczy, co nie wyklucza prawa wyborcy do oddania głosu z zachowaniem odpowiednich środków ochrony zdrowia publicznego. W istocie, o czym poinformowaliśmy pełnomocnika apelującego, a czego ten nie zakwestionował, ustawa ta miała na celu stworzenie rozwiązań umożliwiających przeprowadzenie wyborów oraz zagwarantowanie prawa obywateli Singapuru do głosowania, jak również ochrony interesów całej społeczności przed zachorowaniem w trakcie tego szczególnie trudnego dla całego społeczeństwa okresu. 
b) pełnomocnik strony następnie podniósł, że jest ponad 200 tys. obywateli Singapuru przebywających w dniu głosowania za granicą, którzy mogą nie mieć możliwości oddania głosu z uwagi na ograniczenia w podróżowaniu. Jednakże nie był w stanie podać konstytucyjnej podstawy, w oparciu o którą rząd miałby być zobowiązany do zapewnienia każdemu obywatelowi Singapuru niezależnie od miejsca zamieszkania możliwości oddania głosu. Wskazał na zasadę supremacji konstytucji wynikającą $\mathrm{z}$ art. 4, jednak przepis ten stanowi o nieważności aktów prawnych niezgodnych z konstytucją i nie upoważnia Sądu do wydawania dyrektyw skierowanych do poszczególnych członków władzy wykonawczej w zakresie polityki, którą mają realizować czy wprowadzać. [...]

c) Pełnomocnik strony nie przedstawił innych argumentów w trakcie rozprawy, jednak z pisemnego wniosku wynika kilka kwestii. Przykładowo wskazał, że członkowie komisji wyborczej mogą zostać narażeni na ryzyko podczas wykonywania swych zadań, jednak kwestie zdrowotne nie są związane z prawem do głosowania i powinny być rozpatrywane odrębnie jako kwestia zdrowia publicznego, co nie było przedmiotem żadnej skargi złożonej do Sądu.

14. Z wyżej wymienionych powodów oczywiste jest dla Sądu niewystąpienie naruszenia prawa do wolnych i uczciwych wyborów i nie ma żadnych kontrowersji w tym zakresie. Jak wskazaliśmy wyżej, co do zasady wybory powinny być wolne i uczciwe, jednak po stronie apelującej leży obowiązek wskazania konkretnych aspektów tego prawa, które zostały naruszone, tymczasem żadnego konkretnego aspektu tego prawa apelujący nie wskazał.

\section{Brak interesu prawnego}

15. Ponownie pragniemy podkreślić, że powyższy wywód stanowi wystarczającą podstawę do oddalenia apelacji, należy jednak wskazać również na problemy związane ze stanowiskiem apelującego. W sprawie Vellama d/o Marie vs. Attorney-General („Vellama”) [2013] 4 SLR 1 Sąd stwierdził, że w sytuacji, gdy skarga dotyczy prawa publicznego, apelujący powinien wykazać, że ingerencja lub naruszenie danego prawa stanowiło dla niego osobistą szkodę. Apelujący powinien wykazać, że ,jego osobiste interesy zostały bezpośrednio i faktycznie narażone na szkodę, która objęła również szerszą grupę osób dysponujących tym prawem". Rozważając tę kwestię, przede wszystkim należy zdefiniować naturę analizowanego prawa [...]. Apelujący nie wykazał, że jego prawo do głosowania zostało w istocie naruszone. Odnosząc się do zarzutu dotyczącego sytuacji wyborców przebywających za granicą, należy zauważyć, że apelujący nie należy do tej grupy wyborców. Jeśli chodzi o rekomendacje dotyczące rezygnacji z głosowania, to zarzut ten jest przedwczesny, gdyż nie wiadomo, czy takie rekomendacje zostaną wydane, apelujący nie zadeklarował również, aby wydanie takich deklaracji miało skłonić go do rezygnacji z głosowania. [...] 


\section{Konkluzja}

16. Z powodów wymienionych powyżej oddalamy apelację. [...]. $[\ldots]$

Tłumaczenie i opracowanie: Marcin Rulka*

* Dr Marcin Rulka, Wyższa Szkoła Kadr Menedżerskich w Koninie, marcinrulka2@o2.pl, https://orcid.org/0000-0002-2617-2148

\section{Bibliografia}

Constitution of the Republic of Singapore of 9th August 1965, <https://sso.agc.gov.sg/Act/ CONS1963>.

Parliamentary Election Act of 12th November 1954, <https://sso.agc.gov.sg/>.

Parliamentary Elections (COVID-19 Special Arrangements) of 1st June 2020, <https://sso.agc. gov.sg/>. 